\title{
The Difference of Olfactory Functions in The Workers of The Gas Station by Using Sniffin' Stickstest in Medan City
}

\author{
Irwan Pernandi Sagala ${ }^{\# 1}$, Delfitri Munir ${ }^{1}$, Andrina Yunita Murni Rambe ${ }^{1}$, \\ Taufik Ashar $^{2}$ \\ ${ }^{I}$ Department of Ear Nose Throat Head and Neck, Faculty of Medicine Universitas Sumatera Utara, \\ Indonesia
}

${ }^{2}$ EPI-TREAT Unit University of Sumatera Utara

\begin{abstract}
Introduction: Chronic exposure of volatile substances can cause the impaired olfactory function. Objectives: In order to identify the difference of olfactory function in the workers of the Gas Station in Medan city. Methods: Analytical research with cross-sectional approach. The research subjects were 80 persons consisting of 40 gas station operators and 40 non-operators who fulfilled the inclusion and exclusion criteria. The applied statistical analysis was Mann Whitney, Fisher's Exact, Chi Square, T independent, Spearman with 95\% confidence level. Results: Proportion of the impaired olfactory function in the gas station operator group by $77.5 \%$ and non-operator group by $0 \%$. Significant correlation was obtained between age, duration of work with the impaired olfactory function $(p=0,047, p=0,001)$. The gas station operators will suffer the impaired olfactory function if they work for $\geq 3.89$ years. Conclusions: There were differences of olfactory functions in the gas station workers by using Sniffin 'Sticks Test in Medan city.
\end{abstract}

Keyword: Volatile Substance, Olfactory Function, Sniffin's Test, Gas Station Received 30 May 2018 | Revised 10 July 2018 | Accepted 25 September 2018

\footnotetext{
*Corresponding author at: Faculty of Medicine, Jalan Doktor Mansyur No.5 Kampus USU Padang Bulan, Medan,
} Sumatera Utara 20155 


\section{Introduction}

The nose serves as an olfactory organ that plays an important role to protect people from environmental hazards such as gas leaks, rotten foods, fires, smoke and air pollution. When breathing air, the nasal cavity is the initial injured part due to exposure to inhaled irritants, in which the particles are deposited, and absorption of potentially hazardous gas and vapor [1].

Fuel oil as a widely-used product by humans containing volatile and non-volatile components with sufficient degrees of distillation. Under normal circumstances for users of fuel oil and fuel oil production facilities, the exposure can generally occur through inhalation or volatile substances.

Fuel oil will cause acute or chronic inflammation, which further limits the airflow to the olfactory region or stimulates the toxic metabolism in the epithelium, ultimately damaging the olfactory epithelium. Inflammation may also decrease immunoglobulin A of the upper respiratory tract, thus allowing colonization of pathological bacteria in the olfactory mucous membranes and will cause damage to the olfactory mucosa. Chronic exposure to fuel oil can also lead to chemical burns trauma on the olfactory epithelium that may cause anosmia [2].

Fuel oil is the most commonly found toxin substance especially in gas station workers. This compound can cause olfactory epithelial damage if chronic exposure occurs at least 5 minutes to 3 days.

In 2014 , the research on gas station workers obtained 20 the male subjects $(27 \%)$ of 46 persons with the impaired olfactory function, and 10 persons (13.5\%) female subjects of 28 persons suffering from the impaired olfactory function [3].

\section{Methodology}

This research was an analytic research with cross-sectional study. The population of this research was all workers of 5 gas stations in Medan city. The sample of this research was some of population members examined by the researcher and met the inclusion criteria. The inclusion criteria are workers of $<60$ years old, have working period of $>6$ months, in anamnesis and ENT examination it discovered no acute or chronic rhinitis, neurological disorders, nasal surgery, polyps, konka hypertrophy, septum deviation, nasal tumor, no records of nasal and head trauma and willing to be included in the research and signing the informed consent.

Number of samples were 80 people (operator $=40$ persons and non-operator $=40$ persons). The examination of olfactory function was using Sniffin's sticks test which measured threshold parameters, discrimination, and identification and then measured by adding the three parameters as an TDI score. A score of $\leq 15$ was categorized as anosmia, 16-29 was categorized as hyposmia, and $\geq 30$ was categorized as normosmia. 
Data were analyzed by using SPSS, scrutinized analytically by Mann Whitney, Fisher's Exact, Chi Square, $\mathrm{T}$ independent, Spearman test. This research had been approved by the Research Ethics Committee of the Faculty of Medicine, Universitas Sumatera Utara.

\section{Results}

In this research, the subjects aged 30-39 years were dominant in two groups, 26 persons (65\%) in the gas station operators and 23 persons $(57.5 \%)$ who were non-operators. The average duration of service of the gas station operators was 3.20 years and non-gas station operators have been working for 3.88 years (Table 1).

Table 1. Demographic Characteristics of Research Subjects

\begin{tabular}{lcc}
\hline $\begin{array}{l}\text { Demographic } \\
\text { Characteristics }\end{array}$ & \multicolumn{2}{c}{ Gas Station Operator } \\
\cline { 2 - 3 } Gender, n (\%) & Yes $(\mathbf{n = 4 0 ) ( \% )}$ & No $(\mathbf{n = 4 0})(\%)$ \\
Male & $19(47,5)$ & $20(50)$ \\
Female & $12(30)$ & $5(12.5)$ \\
$20-29$ years & $26(65)$ & $23(57,5)$ \\
$30-39$ years & $2(5)$ & $12(30)$ \\
$\geq 40$ years & $3,20(2,10)$ & $3,88(1,51)$ \\
Lama Kerja, rerata (SB) & &
\end{tabular}

In the subjects who worked as gas station operators, the total score of TDI was 23,39 (SD $=6,99)$, which suffered with anosmia were 8 people (20\%) and hyposmia were 23 people $(57,5 \%)$. Whereas in the non-gas station operator, it obtained total score of TDI by 32,64 $(\mathrm{SD}=1,10)$ and all workers have normal olfactory function. In the Mann Whitney test, it obtained significant differences for threshold parameters, discrimination, identification between operators and nonoperators of gas station workers $(\mathrm{p}<0.05)$ (Table 2). 
Table 2. Differences in The Olfactory Function Between Gas Station

Operators and Non-Operators

\begin{tabular}{lccc}
\hline \multirow{2}{*}{$\begin{array}{l}\text { Olfactory } \\
\text { Function }\end{array}$} & \multicolumn{3}{c}{ Gas Station Operator } \\
\cline { 2 - 4 } Yes (n=40](SD) & No (n=40)(SD) & $\mathbf{p}^{*}$ \\
\hline Threshold & $7,81(3,80)$ & $12.86(0,82)$ & $<0,001^{\mathrm{a}}$ \\
Discrimination & $7.55(2,67)$ & $10,13(0.94)$ & $<0,001^{\mathrm{a}}$ \\
Identification & $8.03(1.78)$ & $9.65(1.12)$ & $0.001^{\mathrm{a}}$ \\
TDI & $23.39(6.99)$ & $32.64(1.10)$ & $<0,001^{\mathrm{a}}$ \\
Olfactory & $31(77,5)$ & 0 & $<0.001^{\mathrm{b}}$ \\
Impairment (\%) & & & \\
Normosmia, $\mathrm{n}(\%)$ & $9(22.5)$ & $40(100)$ & \\
\hline
\end{tabular}

${ }^{\mathrm{a}}$ Mann Whitney, ${ }^{\mathrm{b}}$ Wisher's Exact

The proportion of subjects aged 20-29 years who suffered from the impaired olfactory function were 5 persons (29.4\%), subjects aged 30-39 years were 24 (49\%) and subjects aged $\geq 40$ years were $2(14.3 \%)$. The result of analysis using Chi Square test represented that there was a significant correlation between age and the impaired olfactory function $(p=0,047)$ (Table 3).

Table 3. Correlation Between Age and The Impaired Olfactory Function of All Subjects

\begin{tabular}{lccc}
\hline \multicolumn{1}{c}{ Age } & \multicolumn{3}{c}{ The impaired olfactory function } \\
\cline { 2 - 4 } & Yes & No & P \\
\hline 20-29 years & $5(29,4)$ & $12(70,6)$ & 0,047 \\
30-39 years & $24(49)$ & $25(51)$ & \\
$\geq$ 40 years & $2(14,3)$ & $12(85,7)$ & \\
\hline * & & &
\end{tabular}

In the group of subjects who worked as gas station operators, the mean age who suffered from the impaired olfactory function was 34.03 years ( $\mathrm{SD}=3.64$ years), while the non-impaired ones were 25.11 years $(\mathrm{SD}=4.83$ years $)$.

In the group of subjects who worked as gas station operators, the mean length of working of the subjects who suffered from the impaired olfactory function was 3.89 years ( $\mathrm{SD}=1.87$ years) while the non-impaired subjects were 0.82 years $(\mathrm{SD}=0.19$ years). The result of analysis using Mann whitney test discovered significant correlation between the length of work with the impaired olfactory function $(\mathrm{p}=0,001)$ (Table 4). 
Table 4. Correlation Between Age and Length of Work With

The Impaired Olfactory Function of The Gas Station Operators

\begin{tabular}{lccc}
\hline \multicolumn{3}{c}{ The Impaired Olfactory Function } \\
\cline { 2 - 4 } & Yes (SD) & No (SD) & P \\
\hline $\begin{array}{l}\text { Age, mean (SD), } \\
\text { years }\end{array}$ & $34,03(3,64)$ & $25,11(4)$ & $<0,001^{\mathrm{a}}$ \\
$\begin{array}{l}\text { Length of work, } \\
\text { means(SD), years }\end{array}$ & $3.89(1,87)$ & $0,82(0,9)$ & $<0.001^{\mathrm{b}}$ \\
$\begin{array}{l}\text { andependen, }{ }^{\mathrm{b}} \text { Mann Whitney } \\
\text { Ind }\end{array}$ &
\end{tabular}

\section{Discussion}

The impaired olfactory function as a risk due to exposure to fuel oils containing benzene, toluene, ethylbenzene, and xylene have long been the subject of discussion. However, around 1990, benzene has been used as an indicator of exposure to fuel oil, especially on workers at the gas station. In Nordic countries, the concentration of benzene in fuel oil ranges from $2-6 \%$ and the length of work allowed is 8 hours per day. Nordic gas station workers are exposed to benzene about $0.5-1 \mathrm{mg} / \mathrm{m}^{3}$. Exposure to fuel oil vapor at gas stations mainly occurs at the time of filling into the car tank. Filling as much as 30 liters containing $5 \%$ volume of benzene into the car tank, then there will be about $700 \mathrm{mg}$ of the inhaled benzene. Total concentration of hydrocarbons in the air during the refueling process is 10 to 100 times of benzene [4].

In this study, the total score of TDI on subjects who worked as gas station operators was 23.39 and 8 persons (20\%) suffered from anosmia, 23 persons $(57,5 \%)$ had hyposmia. While total score of TDI on subjects who worked as non-gas station operator was 32,64 and all workers have normal olfactory function (normosmia). In the Mann Whitney test, the mean value of threshold, discrimination and identification of the olfactory function in the gas station operator was lower than those of the non-gas station operator, and there was a significant proportional difference for the impaired olfactory function in which the gas station operators was higher than those of nongas station operators with a ratio of $77.5 \%$ versus $0 \%$ by Fisher's Exact Test $(p<0.001)$.

The same case was also discovered in the research conducted by Fathoni (2014) in which the obtained numbers were also almost the same that there were 30 persons $(40.5 \%)$ of 74 persons of total subjects who worked at the gas stations have suffered the impaired olfactory function [3]. In research conducted by Agoeng (2013), there were 7 subjects (8.2\%) who suffered from malfunctioning with the mean TDI score of $26.65 \pm 1.24$ (hyposmia) while those with no impairment were 78 subjects (91.8\%) with the mean TDI score of $33.30 \pm 1.63$ (normosmia) [5].

This is in accordance with Riechelmann's theory (2004), which mentioned chronic exposure to fuel oil vapors containing volatile substances (benzene, toluene, ethylbenzene, xylene) can lead to the release of P (SP) substances, then it will bind to the NK1 (Neurokinin 1) receptor, which 
triggers the formation of kinase $\mathrm{C}$ protein $(\mathrm{KCP})$ and further leads to hyperactivity of the mucous membrane, process of detoxification and chronic inflammatory with large amounts of neutrophils that can cause damage to olfactory cells and mucin glands that may cause the impaired olfactory function [6,7].

In this study, the proportion of subjects aged 20-29 years suffered from the impaired olfactory function was 5 persons (29.4\%), aged 30-39 years was 24 persons (49\%) and aged $\geq 40$ years was 2 persons $(14,3 \%)$. The result of analysis using Chi Square test represented that there was significant correlation between age and the impaired olfactory function $(p=0,047)$. The results of this study were similar to the results obtained by Fathoni (2014) in which the impaired olfactory function on subjects aged $\geq 40$ years were 6 persons $(8.1 \%)$ and subjects aged $<40$ years were 24 persons $(32.4 \%)$ [3].

Age is closely related to the impaired olfactory function, in which the decline in olfactory function generally occurs from the $5^{\text {th }}$ and $6^{\text {th }}$ decade of life and will undergo a drastic decline in the $7^{\text {th }}$ decade. According to Smith (1942) from the research on 121 specimens of olfactory bulbus obtained from the autopsy result, it was concluded that there was a decrease in the olfactory nerves from birth and throughout life ranging from 1\% per year [8]. In Ulhaq, Tahir and Ione's studies (2008) on 30 human cadavers there was a decrease in number of mitral cells and decreased nuclear size of mitral cell in the olfactory bulbus with the age [9]. It then causes the decreased olfactory function in humans.

In this research, it was discovered that the mean age suffering from the impairment in the group of subjects who worked as gas station operators was 34.03 years $(\mathrm{SD}=3.64$ years), whereas those who had no impairment was 25.11 years ( $\mathrm{SD}=4,83$ years). In the group of subjects who worked as gas station operators, the mean length of works of the subjects who suffered from the impairment was 3.89 years ( $\mathrm{SD}=1.87$ years) while the non-impaired subjects were 0.82 years ( $\mathrm{SD}=0.19$ years). The result of analysis using Mann whitney test discovered significant correlation between length of work with the impaired olfactory function $(p=0,001)$ [10][11].

This is in accordance with the theory stated by Takeuchi (2004) which proposed that chronic exposure by toxin substances that lasted more than 6 months although with low concentration will be able to cause chronic effects on workers, which in this case due to exposure to fuel oil vapor for more than 6 months will cause the impaired olfactory funtion on the workers [12]. 


\section{Conclusion}

There was a significant difference in proportion for the impaired olfactory function by using

Sniffin 'Sticks Test at the Gas Station workers in Medan city by using Fisher's Exact test ( $p$ $<0.001)$.

\section{REFERENCES}

[1] C.E. Ophardt, What Is Gasoline?, Virtual Chembook. (2003).

[2] E. Lynge, A. Andersen, R. Nilsson, L. Barlow, E. Pukkala, R. Nordlinder, P. Boffetta, P. Grandjean, P. Heikkiia, L.-G. Horte, Risk of Cancer And Exposure To Gasoline Vapors, American Journal Of Epidemiology. 145 (1997) 449-458.

[3] A.N. Fathoni, B.U.D. Rianto, Gangguan Penghidu Pada Pekerja Stasiun Pengisian Bahan Bakar Umum (Spbu) Di Yogyakarta, Phd Thesis, Universitas Gadjah Mada, 2014.

[4] J.M. Benson, E.B. Barr, J.R. Krone, Mtbe Inhaled Alone And In Combination With Gasoline Vapor: Uptake, Distribution, Metabolism, And Excretion In Rats., Research Report (Health Effects Institute). (2001) 73-94.

[5] Agung. Hp, Hubungan Paparan Uap Zat Solven Dengan Gangguan Penghidu Pada Karyawan Percetakan Di Pelembang. Departemen Ktht-K1 Rsup Dr. Mohammad Hoesin Palembang., (2013) 1-55.

[6] H. Riechelmann, Cellular and Molecular Mechanisms in Environmental and Occupational Inhalation Toxicology, Gms Current Topics In Otorhinolaryngology, Head And Neck Surgery. 3 (2004).

[7] U. Glück, R. Schütz, J.-O. Gebbers, Cytopathology of The Nasal Mucosa In Chronic Exposure To Diesel Engine Emission: A Five-Year Survey Of Swiss Customs Officers., Environmental Health Perspectives. 111 (2003) 925.

[8] C.G. Smith, Age Incidence Of Atrophy Of Olfactory Nerves In Man. A Contribution To The Study of The Process Of Ageing, Journal of Comparative Neurology. 77 (1942) 589-595.

[9] T.M. Sama-Ul-Haq, K.P. Lone, Age And Gender-Related Differences in Mitral Cells of Olfactory Bulb, J Coll Physicians Surg Pak. 18 (2008) 669-673.

[10]R.L. Doty, L. Hastings, Neurotoxic Exposure and Olfactory Impairment, Clin Occup Environ Med. 1 (2001) 547-575.

[11]R.L. Doty, P. Shaman, S.L. Applebaum, R. Giberson, L. Siksorski, L. Rosenberg, Smell Identification Ability: Changes With Age, Science. 226 (1984) 1441-1443.

[12]Y. Takeuchi, Health Effects From Exposure To Chronic Levels Of Industrial Chemicals, Environmental Toxicology And Human Health-Volume I. (2009) 57. 